\title{
Risk assessment via oral and dermal pathways from heavy metal polluted water of Kolleru lake - A Ramsar wetland in Andhra Pradesh, India
}

\author{
Subrata Das Sharma ${ }^{1, *(1)}$ \\ ${ }^{1}$ CSIR-National Geophysical Research Institute, Uppal Road, Hyderabad, India \\ *Correspondence: dassharma@rediffmail.com
}

Received: August 15, 2020 Accepted: September 14, 2020

\begin{abstract}
The Kolleru Lake, India is a famous wetland of international significance. Analyses of certain potentially toxic heavy metal ions in water indicate that this freshwater lake is characterized by highly heterogeneous distribution of chromium $(\mathrm{Cr} ; 4.5-80 \mu \mathrm{g} / \mathrm{L})$, copper, iron (Cu, Fe; below detection limit), manganese (Mn; $1-313 \mu \mathrm{g} / \mathrm{L})$ and zinc (Zn; below detection limit). Non-carcinogenic health risk assessment indices like hazard quotients $(H Q)$ and hazard indices $(H I)$ are estimated following the guidelines recommended by the US Environmental Protection Agency (USEPA). These indices are found to be within the acceptable limit $(<1)$, indicating negligible potential health risk via ingestion and dermal routes. However, when the average values of these indices pertaining to the Kolleru lake are normalized with similar estimates from clean and uncontaminated global surface water, both high and low ratios are obtained. While $\mathrm{Cr}(12.5), \mathrm{Cu}(2.3)$ and $\mathrm{Mn}$ (3.7) exhibit high ratios, those of Fe (0.09) and $\mathrm{Zn}(0.99)$ show respectively low and comparable values. The significance of such heterogeneous distribution of hazard indices and their ratios are discussed. Further, average carcinogenic risk levels of the adults and children due to $\mathrm{Cr}$ ingestion are estimated to be 0.00154 and 0.0022 , respectively. Both values are higher than the permissible levels recommended by the USEPA. As a remediation measure, it is recommended that monitoring the levels of heavy metal in water and other items like fish in the lake or rice and vegetables grown in the area is needed to be carried out at regular intervals. This study therefore offers requisite perception to the local government and health officials to evolve their plan of action so that effective management and mitigation of water quality of the Kolleru lake can be administered.
\end{abstract}

Keywords: Kolleru Lake, Water pollution, Toxic heavy metals, Chronic daily intake, Health hazard indices

\section{Introduction}

Over the past three decades, the environment has progressively deteriorated leading to air, water, and soil pollution. Rapid industrialization and diverse-natured anthropogenic activities are the major causes contributing to quality decline in most of the cases [1-4]. In addition, geogenic sources (naturally occurring) are also cited as contaminants in some instances [5,6]. It has been estimated that about one third of people in the world are deprived of safe drinking water [7]. Contaminated water and poor sanitation are linked to transmission of many diseases like cholera, dysentery, hepatitis A, typhoid, etc. [7]. Contaminants in drinking water are classified into four categories: (i) physical contaminants (sediment or organic material suspended in water), (ii) chemical contaminants that are either naturally occurring or anthropogenic (e. g., nitrogen, bleach, salts, pesticides, metals and heavy metals, toxins produced by bacteria, and human or animal drugs), (iii) biological contaminants (i.e., organisms in water such as bacteria, viruses, protozoan, parasites, etc), and (iv) radiological contaminants (elements made up of atoms having unstable nuclei that emit ionizing radiation).

Safe Drinking Water Committees under the aegis of the National Research Council in the US addressed the issue related to contamination of drinking water during 1977-1987. They evolved a systematic scientific and administrative scheme to assess health risks associated with exposure to toxic chemicals in drinking water [8-10]. Subsequently many studies were conducted globally to assess the quality of drinking water and health risks associated with ingestion of contaminated groundwater and surface water $[3,4,6,11,12]$. Health risk caused by heavy metals in a water source is an active area of research in recent years. This is because, depending on the heavy metal and its chemical form in water, prolonged exposure can affect target tissues such as brain, liver, bones, and kidneys in the human body resulting in serious health 
problems [13]. Therefore, health risk assessment is an essential part, where an evaluation is made to assess the possible health effects of groundwater and/or surface water bodies that are contaminated.

Among the surface water bodies, lakes provide livelihood to many people across the globe. In developing countries, more than 60 million people rely on lakes for their income [14]. However, pollution of lake ecosystem and its surroundings due to anthropogenic activities has become a major global issue in many parts of the world $[15,16]$. In India, the dependency on lakes for livelihood is also seen in different parts as evidenced from the explosion of agricultural and livestock farming, fishery industries and tourism around many lakes of the country [17-19]. All these Indian lakes are subjected to human-induced adverse impacts, which are undesirable.

The Kolleru lake is one of the largest natural freshwater lakes in India located in the southern state of Andhra Pradesh. In August 2002, the lake has been designated as a wetland of international importance [20] under the International Ramsar Convention. Wetlands are of considerable economic importance, as they nourish diverse biota and are natural habitat for a large variety of resident and migratory birds. Naturally, the Kolleru lake was also a "paradise of birds" and used to be a place of tourist attraction. However, during the past two decades the lake habitat has degraded significantly owing to various anthropogenic activities around its vicinity that include intensive agricultural, industrial and farm activities [21-25]. Despite being one of the largest freshwater lakes, it is irony that the area surrounding the Kolleru lake has acute shortage of drinking water [26]. Moreover, there is extreme poverty in the region that still persists [27]. It is therefore likely that majority of poor residents are forced to use lake water for drinking and other purposes.

As pointed out above, a number of studies were conducted to estimate the quality of Kolleru lake water and sediments, besides digital processing of IRS-1D LISS-III sensor data of the lake region [21-25]. However, no work following the guidelines recommended by the US Environmental Protection Agency (USEPA) on human health risk assessment has been attempted so far. In view of this, health hazard risk assessment is carried out in this study. Concentrations of six heavy metals in the Kolleru lake water that include cadmium $(\mathrm{Cd})$, chromium $(\mathrm{Cr})$, copper $(\mathrm{Cu})$, iron $(\mathrm{Fe})$, manganese $(\mathrm{Mn})$, and Zinc (Zn) were analysed. Non-carcinogenic health risks associated with these heavy metals are estimated due to drinking and dermal absorption for general adults and children in the community. An attempt is also made to estimate cancerous health risk associated with ingestion of lake water contaminated with carcinogenic toxic metals. Significantly, the results of this new research may provide some insight to the local government and health professionals to evolve strategies to effectively manage water quality, and hence to revive the pristine glory of the Kolleru lake ecosystem.

\section{Materials and Methods Study area}

In view of international significance of the area (Ramsar site), a brief account of the study area is presented first. Kolleru lake, located between the latitudes $16^{\circ} 32^{\prime}$ and $16^{\circ} 47^{\prime} \mathrm{N}$ and longitudes $81^{\circ} 05^{\prime}$ and $81^{\circ} 27^{\prime} \mathrm{E}$, is the largest natural freshwater lake in the southern state of Andhra Pradesh. The lake lies between the deltas of two main rivers, Godavari and Krishna and it is approximately $35 \mathrm{~km}$ inland from the present shoreline (Figure 1). There are three main streams that drain into the lake. These streams are known as Budimeru, Thammileru and Ramileru. The lake finally drains itself to the Bay of Bengal through Upputeru river [24,25]. It is a shallow freshwater body with a natural spread of $\sim 674 \mathrm{~km}^{2}$. However, its areal extent goes up to $\sim 954 \mathrm{~km}^{2}$ during the rainy seasons when highest floods are recorded in the area. On the other hand, during dry seasons the areal extent comes down to as low as $\sim 66 \mathrm{~km}^{2}$. It is significant to note that the lake also serves as a natural flood-balancing reservoir for the two major rivers- Godavari and Krishna. Fluvio-marine deposits (sand, silt and clay) characterize the lake surroundings from all sides. The nearest rock formations occur about $10 \mathrm{~km}$ away from the lake. The geological formations include khondalite, Gondwana, Deccan traps and tertiary sediments [28].

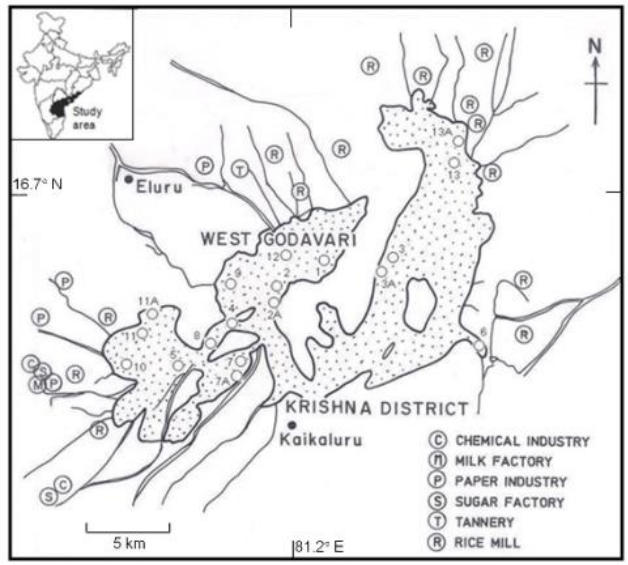

Figure 1. Map showing Kolleru Lake. Two prominent towns close to the lake, viz., Eluru and Kaikaluru together with various anthropogenic inputs surrounding the lake area [21] are shown. Eighteen sampling points for water are marked by open circles. The horizontal scale $(5 \mathrm{~km})$ displayed in the figure corresponds to $0.045^{\circ}$. The geographical location of the lake (study area) in the state of Andhra Pradesh, India is marked in the inset. 


\section{Sample collection, preparation, and analysis}

Eighteen sampling points were selected to cover the lake area (Figure 1). Uniform sampling could not be carried out due to inaccessibility of some of the locations. The water samples were collected following standard procedure [29]. Polypropylene bottles $(1 \mathrm{~L})$ for sample collection were soaked in $5 \% \mathrm{HNO}_{3}$ for $24 \mathrm{~h}$ followed by rinsing them a number of times with deionized water. The bottles were dried and water samples were collected in duplicate after filtration using Whatman No. 40 filter paper. The $\mathrm{pH}$ and total dissolved solids (TDS) were measured in the field. The $\mathrm{pH}$ electrode was calibrated with $\mathrm{pH} 4$ and $\mathrm{pH} 9.2$ buffer solutions. The samples were then acidified with $5 \mathrm{~mL}$ of $\mathrm{HNO}_{3}$ to prevent the adsorption of heavy metals onto the bottle walls and transported to the laboratory. Until use, preservation of these water samples was done following the recommendations of USEPA [29]. The heavy metal analyses were done in the laboratory within 2 to 3 weeks of the sample collection. The concentrations of cations such as $\mathrm{Cd}, \mathrm{Cr}, \mathrm{Cu}, \mathrm{Fe}, \mathrm{Mn}$, and $\mathrm{Zn}$ were determined by ICP-OES (model Optima 4300 DV; PerkinElmer Life and Analytical Sciences, Shelton, CT, USA) using the standard procedure [30]. The instrument is equipped with a cross-flow nebulizer, Scott spray chamber, echelle grating, and segmented array charge-coupled device detector. The basic principle of operation of ICP-OES is that depending on the heavy metal contents in the sample, each element emits energy at specific wavelengths. However, based on the intensity of the emitted waves it is generally common to select a single wavelength for a given element. The intensity of energy emitted at the chosen wavelength is proportional to the concentration of the element of interest in the sample. It is thus possible to quantify the concentration of the element of interest in the sample relative to a reference standard using a calibration curve. During the course of analysis, a multi-elemental solution from Spex Certiprep, WP-15-500, (Spex, Metuchen, NJ, USA) was used for calibration. A process blank was also prepared, which was run along with samples and corrected for matrix effects.

\section{Governing equations for health risk assessment}

According to the USEPA, "a human health risk assessment is the process to estimate the nature and probability of adverse health effects in humans who may be exposed to chemicals in contaminated environmental media, now or in the future"[31]. Pollutants such as $\mathrm{Cd}, \mathrm{Cr}, \mathrm{Cu}, \mathrm{Fe}, \mathrm{Mn}$, and $\mathrm{Zn}$ were selected in this study. The health risk assessment of each heavy metal contaminant in water is based on the estimation of the risk level. The methods delineated by the USEPA [32,33] have been used to estimate the average chronic daily intake (CDI) from direct ingestion and dermal absorption routes, respectively. The governing equations are as follows:

$$
\begin{aligned}
& C D I_{\text {ingestion }}=\frac{C_{w} \times I R \times E F \times E D}{B W \times A T} \\
& C D I_{\text {dermal }}=\frac{C_{w} \times S A \times K p \times E T \times E F \times E D \times C F}{B W \times A T}
\end{aligned}
$$

where CDIingestion/dermal is expressed in $\mu \mathrm{g} / \mathrm{kg} /$ day; $C_{w}$ is the measured concentration of chemicals in water $(\mu \mathrm{g} / \mathrm{L}) ; I R$ is the ingestion rate (3.5 L per day for adults [34]; $1.32 \mathrm{~L}$ per day for children [35]); $E F$ represents the exposure frequency ( $E F=365$ days per year); $E D$ is the exposure duration $(E D=70$ years for carcinogenic risk and 30 years for non-carcinogenic risk for adults; 6 years for non-carcinogenic risk for children [32, 33]); $B W$ is the average body weight (57.5 kg for adults [36] and 15 $\mathrm{kg}$ for children $[32,33]) ; A T$ refers to the average time representing the period over which exposure is averaged $(A T=25,550$ days for carcinogenic risk and 10950 days for non-carcinogenic risk for adults; 2190 days for children [32,33]); $S A$ is exposed skin area available for contact $\left(18000 \mathrm{~cm}^{2}\right.$ for adults; $6600 \mathrm{~cm}^{2}$ for children [33]); ET is exposure time (0.58 h/day for adults; $1 \mathrm{~h} /$ day for children [33]); $\mathrm{CF}$ is unit conversion factor $\left(0.001 \mathrm{~L} / \mathrm{cm}^{3}\right.$ [33]); and $K p$ is dermal permeability coefficient (cm/h) of heavy metal in water [33].

The hazard quotient $(H Q)$ is an estimate of the toxicity potential posed by an element from direct ingestion or dermal absorption routes, which can be calculated using the relation:

$$
H Q_{\text {ingestion } / \text { dermal }}=\frac{C D I_{\text {ingestion } / \text { dermal }}}{R D_{\text {ingestion } / \text { dermal }}}
$$

where $R f D_{\text {ingestion/dermal }}$ represents oral/dermal reference dose $(\mu \mathrm{g} / \mathrm{kg} /$ day) $[32,33])$ of each contaminant under consideration. In general, $R f D$ is an approximate estimate of daily exposure to the human (including sensitive subgroups) that is likely to have any noticeable risk of harmful effects during a lifetime [32,33]. The $R f D$ estimate may have an uncertainty spanning perhaps an order of magnitude.

The hazard index $(H I)$ is the overall potential for non-carcinogenic effects posed by more than one contaminants via ingestion or dermal pathway, which can be estimated from the relation:

$H I_{\text {ingestion } / \text { dermal }}=\sum_{i=1}^{n} H Q_{\text {ingestion } / \text { dermal }}$

Carcinogenic risk $(C R)$ associated with the ingestion pathway can be estimated using the formula:

$$
C R_{\text {ingestion }}=\frac{C D I_{\text {ingestion }}}{C S F_{\text {ingestion }}}
$$


where CSFingestion represents the cancer slope factor. Of the selected six heavy metals, $\mathrm{Cd}$ and $\mathrm{Cr}$ have significant cancer risk.

\section{Results and discussion}

The $\mathrm{pH}$ of water samples from Kolleru lake are near neutral to alkaline ( $\mathrm{pH}$ varying from 6.8 to 8.8 ; Table 1). The TDS in these waters are variable ranging from 1006 to $5285 \mathrm{mg} / \mathrm{L}$. Such high TDS contents indicate brackish water that has typical TDS contents of $1000 \mathrm{mg} / \mathrm{L}$ or more [37]. In a previous study, it was demonstrated that there exists a two-component mixing relationship between $\mathrm{Na}^{+}$content of lake water and $\delta^{18} \mathrm{O}$ composition of the carbonate fraction of surface sediments of the Kolleru lake [24]. Two-component mixing trend was also evident from cross-plot between $\log (\mathrm{TDS})$ and $\delta^{18} \mathrm{O}$ values. Taken together, such mixing trends are indicative of influx of significant amounts of seawater into the lake [24]. Several human-induced activities in and around the lake have led to almost near stagnant to dry condition of the lake with reduced inflow and outflow, overexploitation of groundwater surrounding the lake area and breached distributaries in Upputeru River, ultimately facilitating significant intrusion of seawater [24].

\section{Heavy metal distribution in Kolleru lake}

The range, average and standard deviation of the concentrations of trace metals $\mathrm{Cr}, \mathrm{Cu}, \mathrm{Fe}, \mathrm{Mn}$ and $\mathrm{Zn}$ in the water samples of Kolleru lake are presented in Table 1. The concentration of Cd was found to be below detection limit for each sample, so I refrain from any further discussion on $\mathrm{Cd}$ in the later part. It is important to mention that of all the water samples \#7 is characterized by maximum concentrations of $\mathrm{Cu}$ and $\mathrm{Cr}$, although the Fe concentration of this sample is below the detection limit. Hence this particular site (Figure 1) is anomalous.

The normalized concentration ratio of five heavy metals is presented in Figure 2. The normalization is carried out with respect to the median values of concentration of these toxic elements that were reported for clean and uncontaminated surface waters (data from Langmuir [38]). Values in excess of 1 indicate enrichment and those below 1 specify depletion. It can be seen from Figure 2 that $\mathrm{Cr}$ is enriched and Fe is depleted, while the other elements like $\mathrm{Cu}, \mathrm{Mn}$ and $\mathrm{Zn}$ show both enrichment as well as depletion at various locations (Figures 1 and 2). Figure 2 points to the fact that the distribution of the analyzed elements in water of the lake is highly heterogeneous, indicating that both free flow and internal mixing of water in the lake is obstructed.

As pointed out above, there are several anthropogenic activities which include unrestrained use of fertilizers and pesticides, fishpond discharges containing high concentrations of pesticides, polycyclic aromatic hydrocarbon (PAH) and heavy metals as indicated from the presence of such contaminants documented in the prawns cultivated in the area, discharge of industrial effluents and agricultural run-off carrying inorganic contaminants [27]. Further, 67 drains varying in length from $0.4 \mathrm{~km}$ to $280 \mathrm{~km}$ discharges water into the Lake [27]. Therefore, it is very difficult to pinpoint the exact source/sources that could be responsible for the observed high concentration in sample $\# 7$.

\section{Non-carcinogenic health risk assessment}

Health risk assessment has been carried out to explore the effect of heavy metals due to ingestion as well as dermal pathways on adults and children. Non-carcinogenic $H Q$ values pertaining to each heavy metal for adults and children are presented in Figures 3 and 4.

Table 1. Range, average and standard deviation of various parameters, $\mathrm{pH}$, total dissolved solids (TDS), and concentrations of five trace metals, chromium $(\mathrm{Cr})$, copper $(\mathrm{Cu})$, iron $(\mathrm{Fe})$, manganese $(\mathrm{Mn})$ and zinc $(\mathrm{Zn})$, in water samples from the Kolleru lake, India. Cadmium (Cd) could not be estimated, as it was below detection limit (BDL) in each sample. In the last row, the average hazard quotient (HQ) estimated for the trace metals dissolved in Kolleru lake water is compared with similar data estimated for uncontaminated global surface water for which the heavy metal contents were reported in Langmuir et al. [38]

\begin{tabular}{|c|c|c|c|c|c|c|c|}
\hline Parameter & $\mathrm{pH}$ & $\begin{array}{c}\text { TDS } \\
(\mathrm{mg} / \mathrm{L})\end{array}$ & $\mathrm{Cr}(\mu \mathrm{g} / \mathrm{L})$ & $\mathrm{Cu}(\mu \mathrm{g} / \mathrm{L})$ & $\mathrm{Fe}(\mu \mathrm{g} / \mathrm{L})$ & $\mathrm{Mn}(\mu \mathrm{g} / \mathrm{L})$ & $\mathrm{Zn}(\mu \mathrm{g} / \mathrm{L})$ \\
\hline Maximum & 8.8 & 5285 & 80.0 & 20.0 & 20.0 & 313.2 & 57.0 \\
\hline Minimum & 6.8 & 1006 & 4.5 & BDL & BDL & 1.0 & BDL \\
\hline Average & 7.7 & 3250 & 12.5 & 6.9 & 9.2 & 55.5 & 21.3 \\
\hline Standard deviation & 0.5 & 1168 & 17.1 & 6.0 & 4.5 & 96.7 & 17.0 \\
\hline$\frac{H Q_{\text {Metal ingestion/dermal }}^{\text {Kolleru Lake }}}{H Q_{\text {Metal ingestion } / \text { dermal }}^{\text {Global Surfacer }}}$ & & & 12.5 & 2.3 & 0.09 & 3.7 & 0.99 \\
\hline
\end{tabular}




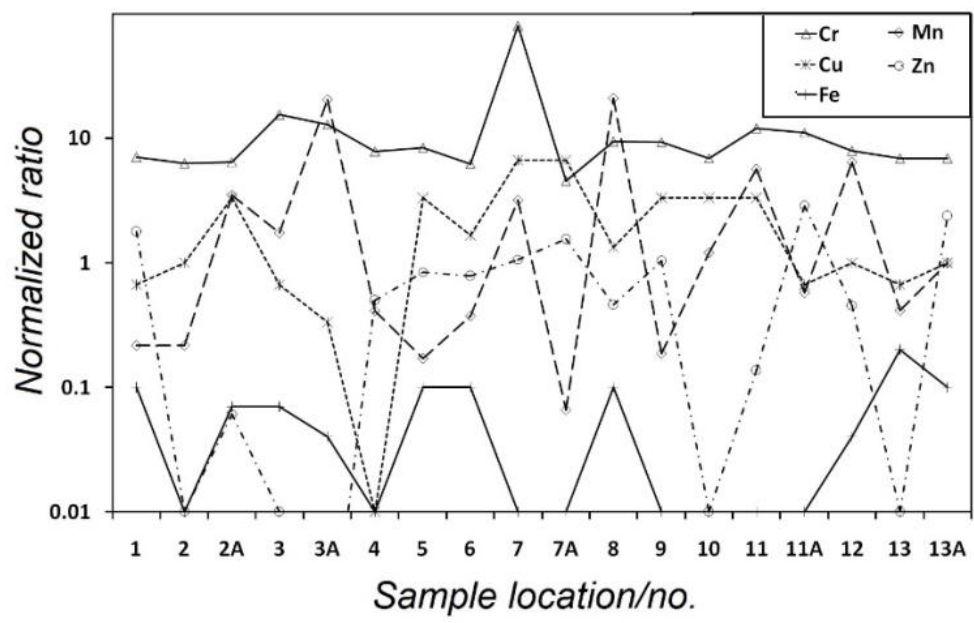

Figure 2. Plot showing heavy metal contaminated water chemistry of the Kolleru lake. The normalized ratios of selected toxic trace metals in the water samples of the lake are plotted for individual sampling site. For normalization, data from Langmuir [38] is used. Note that values greater than 1 indicate enrichment and those lower than 1 specify depletion.

\section{Oral pathway and dermal pathways}

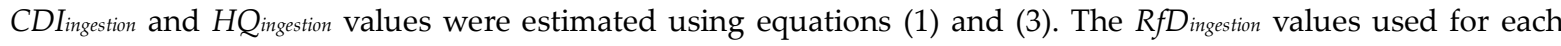
heavy metal are as follows: $\mathrm{Cr}=3 \mu \mathrm{g} / \mathrm{kg} /$ day [39], $\mathrm{Cu}=40 \mu \mathrm{g} / \mathrm{kg} /$ day [40], $\mathrm{Fe}=700 \mu \mathrm{g} / \mathrm{kg} / \mathrm{day}$ [41], $\mathrm{Mn}=140 \mu \mathrm{g} / \mathrm{kg} / \mathrm{day}$ [42] and $\mathrm{Zn}=300 \mu \mathrm{g} / \mathrm{kg} /$ day [43].

Figure 3 shows that for both adults and children the average $H Q_{\text {ingestion }}$ values exhibit the following order: $\mathrm{Fe}<\mathrm{Zn}$ $<\mathrm{Cu}<\mathrm{Mn}<\mathrm{Cr}$. For adults, the $H Q_{\text {ingestion }}$ values for chromium show a wide range (0.093 to 1.636) with a mean value of 0.256 . In the case of children, a wide range ( 0.133 to 2.346$)$ is also characteristic with a mean value of 0.368 . Only one sample is characterized by $H Q_{\text {ingestion }}$ value, which is greater than 1 (sample \# 7, Figure 3a). The $H Q_{\text {ingestion }}$ values for $\mathrm{Cu}, \mathrm{Fe}, \mathrm{Mn}$ and $\mathrm{Zn}$ (Figure $3 b$ to $3 e)$ exhibit respectively the following ranges in the case of adults: ( 0 to 0.03 ; mean $=0.01),(0$ to 0.002 ; mean $=$ $0.0008)$, $(0.0004$ to 0.137 ; mean $=0.024)$ and $(0$ to 0.012 ; mean $=0.004)$. For children, these ranges are: $\mathrm{Cu}=0$ to $0.044, \mathrm{Fe}=0$ to $0.0025, \mathrm{Mn}=0.0006$ to 0.197 and $\mathrm{Zn}=0$ to 0.017 with respective mean values of $0.015,0.0012,0.035$ and 0.006 (Figure $3 \mathrm{~b}$ to 3e). Therefore, with the exception of one site where high $\mathrm{Cr}$ concentration is observed (sample \# 7), the HQingestion of lake water corresponding to each heavy metal is estimated to be less than 1 (Figure 3). Further, the $H Q_{\text {ingestion }}$ values in the case of children are always high compared to those of the adults (Figure 3).

$C D I_{\text {dermal }}$ and $H Q_{\text {dermal }}$ values were estimated using Equations (2) and (3), respectively. The dermal permeability coefficient $\left(K_{p}\right)$ values used in equation (2) for $\mathrm{Cr}, \mathrm{Cu}, \mathrm{Fe}, \mathrm{Mn}$ and $\mathrm{Zn}$ were reported earlier, which are 2.0E-03, 1.0E-03, 1.0E03, 1.0E-03 and 6.0E-04, respectively [33]. The RfD dermal values used in Equation (3) corresponding to each heavy metal were taken from the literature [44].

The estimated $H Q_{\text {dermal }}$ values corresponding to five heavy metals are displayed in Figure 4 . As can be seen in the diagram, the average $H Q_{\text {dermal }}$ is characterized by values that are less than 1 . When the spatial distribution of samples within the lake is considered, it is observed that the individual $H Q_{\text {dermal }}$ values corresponding to each metal exhibit wide scatter (Figure $4 \mathrm{a}$ to $4 \mathrm{e}$ ). Another interesting feature that emerges from Figure 4 is that the $H Q_{\text {dermal }}$ values in the case of children are almost double when compared to those of adults.

Summarizing the results on estimation of $H Q$ values due to direct ingestion and dermal absorption routes, it can be inferred that with the exception of one site where high Cr concentration is observed (sample \#7), there is negligible potential risk of either direct intake or other use of lake water that is contaminated with dissolved heavy metals.

Exposures to multiple chemicals may contribute to increased health risks. Therefore, a measure of cumulative risk, $H I$ is estimated. $\mathrm{HI}$ represents the overall potential for non-carcinogenic effects posed by more than one contaminants via ingestion or dermal pathway, which can be estimated using equation (4). Figure $5 \mathrm{a}$ and $5 \mathrm{~b}$ exhibit the Hingestion and HIdermal values corresponding to each site of the lake. Similar to Figure 3 and 4, we observe HIingestion and HIdermal that are characterized by low values $(<1)$, indicating negligible health risk. However, one site is characterized by high HIingestion value (Figure $5 a)$.

\section{Carcinogenic health risk assessment due to chromium $(\mathrm{Cr})$ ingestion}

$C R_{\text {ingestion }}$ of $\mathrm{Cr}$ was estimated using equations (1) and (5). The cancer slope factor (CSF ingestion) for Cr is $500 \mu \mathrm{g} / \mathrm{kg} / \mathrm{day}$ [45]. Figure $5 \mathrm{c}$ shows the histogram plot of estimated $C R_{\text {ingestion }}$ of $\mathrm{Cr}$ for adults and children. The $C R_{\text {ingestion values range from }}$ 


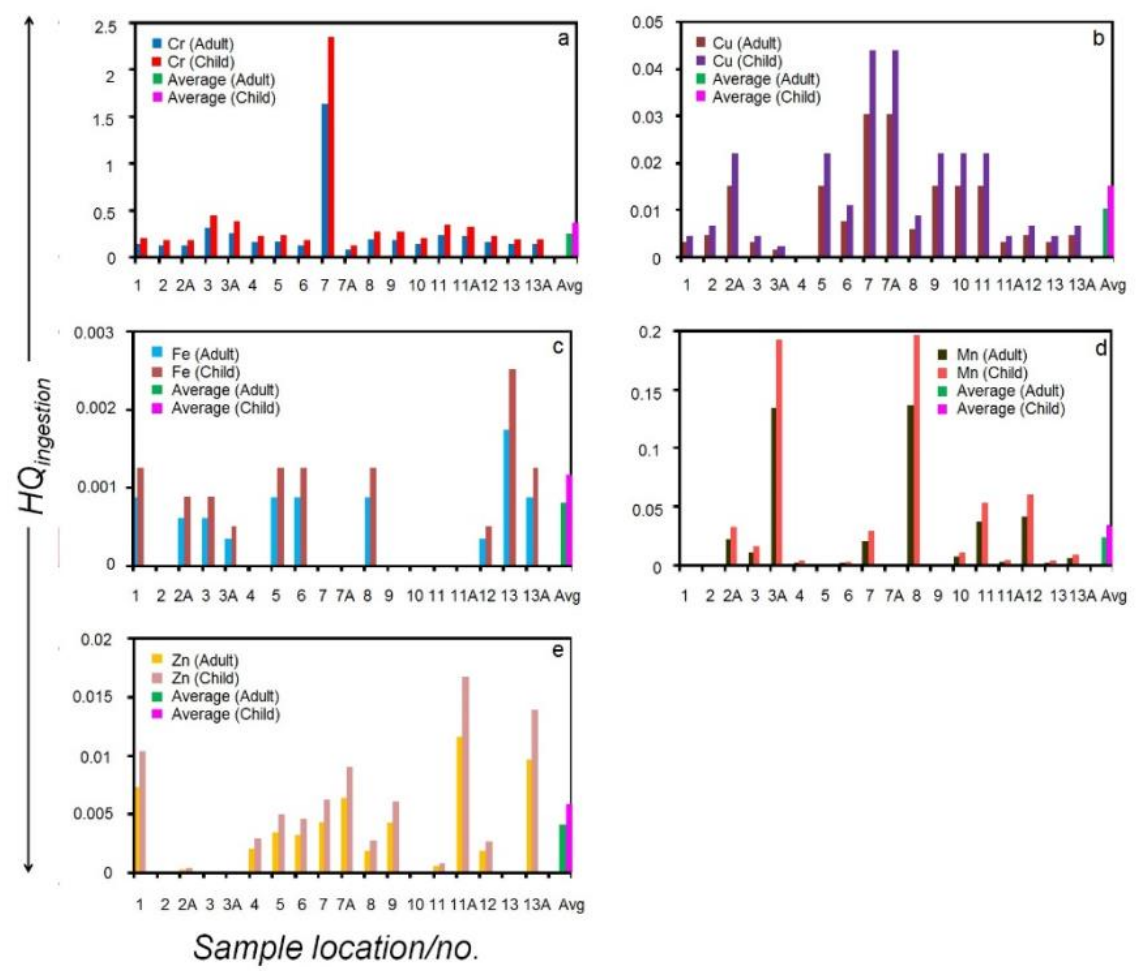

Figure 3. Non-carcinogenic hazard quotient through ingestion pathway ( $H Q_{\text {ingestion }}$ ) of heavy metals, (a) chromium $(\mathrm{Cr})$, (b) copper $(\mathrm{Cu})$, (c) iron (Fe), (d) manganese $(\mathrm{Mn})$ and (e) zinc (Zn), of the Kolleru lake. HQingestion for individual sampling site corresponding to adults, children and the respective averages are shown.

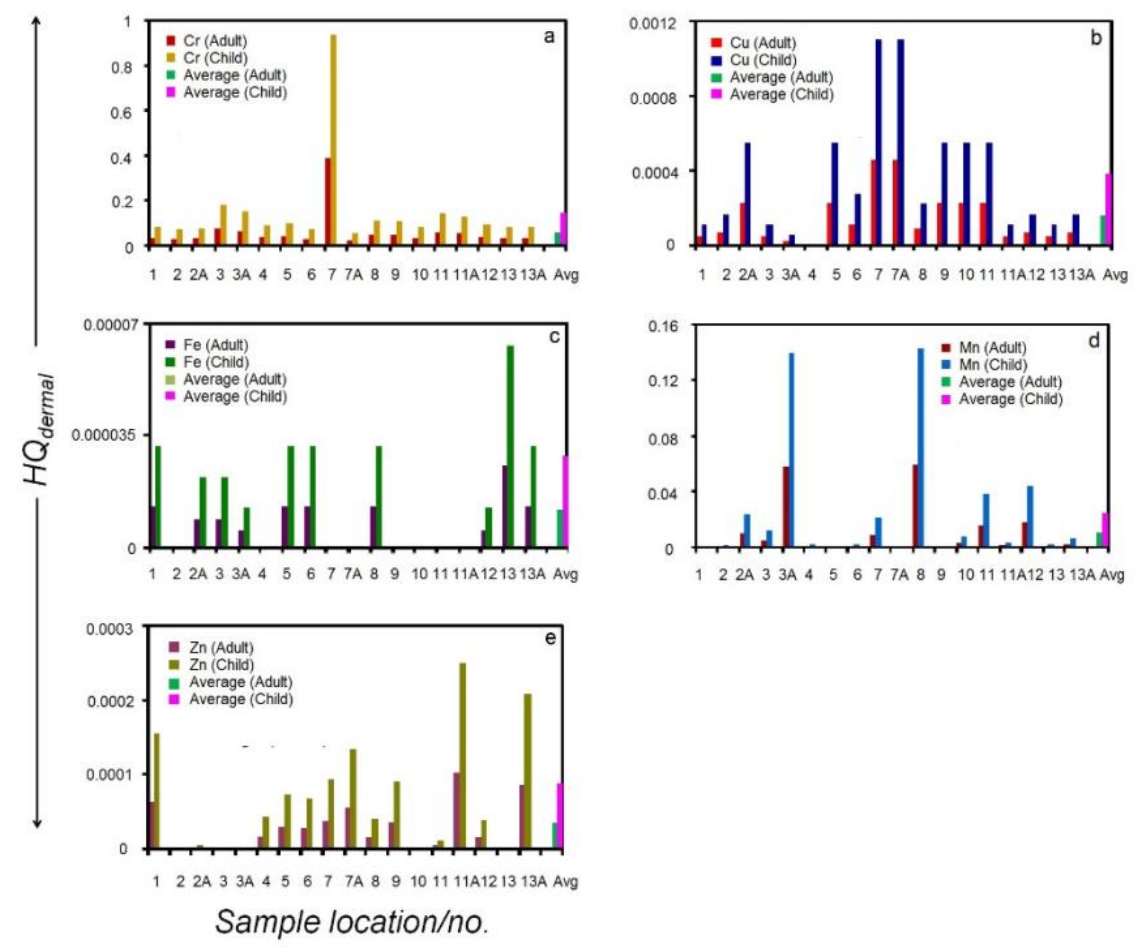

Figure 4. Non-carcinogenic hazard quotient through dermal pathway (HQderaml) of heavy metals, (a) chromium $(\mathrm{Cr}),(\mathrm{b})$ copper $(\mathrm{Cu}),(\mathrm{c})$ iron $(\mathrm{Fe}),(\mathrm{d})$ manganese $(\mathrm{Mn})$ and $(\mathrm{e})$ zinc $(\mathrm{Zn})$, of the Kolleru lake. HQingestion for individual sampling site corresponding to adults, children and the respective averages are shown. 

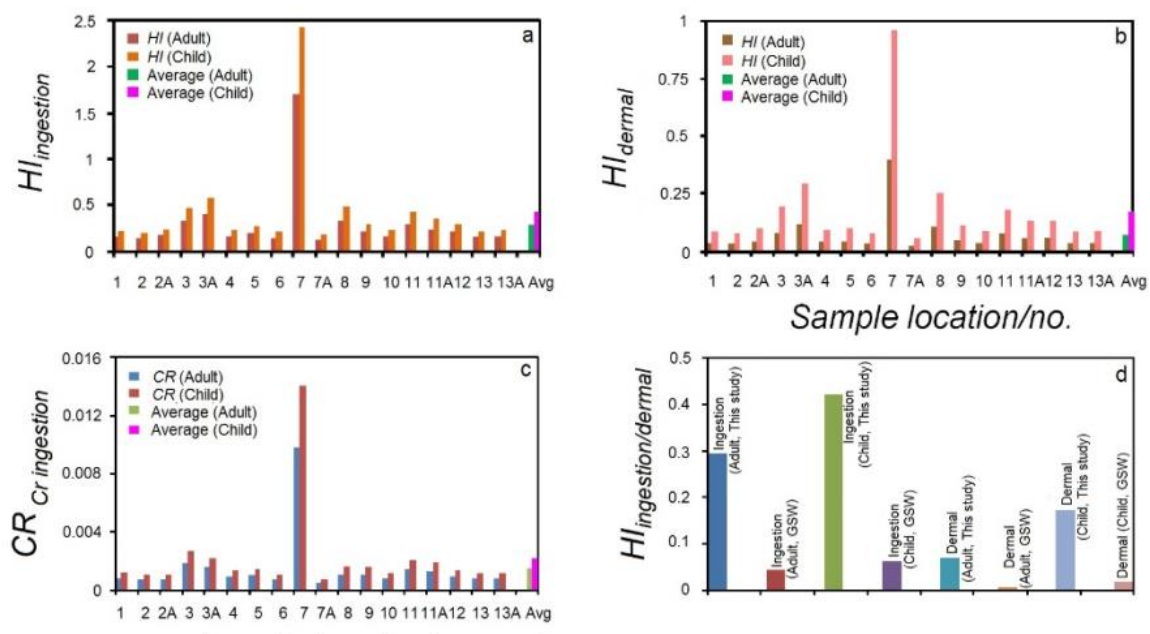

Sample location/no.

Figure 5. Estimated non-carcinogenic hazard index $(H I)$ and carcinogenic risk due to chromium $(\mathrm{Cr})$ ingestion. The bar diagram of hazard index corresponding to adults, children and the respective averages are shown. The $H I$ represents the overall potential for non-carcinogenic effects posed by more than one contaminant via (a) ingestion (HIingestion) and (b) dermal (HIdermal) routes. Histogram plots showing (c) carcinogenic risk due to chromium ingestion ( $\left.C R C_{\text {r ingestion }}\right)$ and (d) comparative study between average Kolleru lake water Hingestion/dermal values and those estimated for global surface water (GSW; [38]).

0.00056 to 0.0098 with an average of 0.00154 for adults. In the case of children, the minimum (0.0008) maximum (0.0141) and average (0.0022) values are higher compared to the adults (Figure 5c). The estimated CRingestion value is indicative of the incremental probability of an individual developing cancer over a lifetime. For example, CRingestion of $10^{-4}$ indicates a probability of 1 in 10,000 individuals developing cancer [32]. Incidentally, according to the USEPA the permissible levels of total carcinogenic health risk is also $10^{-4}$ [46]. The average CRingestion levels of the adults and children are 0.00154 and 0.0022 , respectively. Both these values are therefore higher than the permissible levels [46]. Furthermore, children are more vulnerable to $\mathrm{Cr}$ ingestion.

\section{Comparison of health risk associated with Kolleru lake water vis-a-vis global surface water}

The non-carcinogenic health risk assessment of Kolleru lake water has indicated negligible potential risk via ingestion and dermal routes. However, in the backdrop of Figure 2 shown above, it is important to estimate the health risk associated with global surface water for which the heavy metal contents were reported in Langmuir [38] and compare them with the Kolleru lake water. Table 1 presents the ratio between average $H Q$ values associated with various heavy metals dissolved in Kolleru lake water and global surface water. It can be seen from Table 1 that three heavy metals, Cr, Mn and $\mathrm{Cu}$ are characterized by ratios that are greater than 1 and the ratios follow the order:

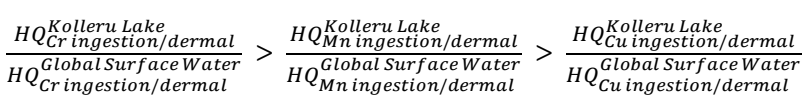

Therefore, $\mathrm{Cr}$ is the major contaminant in the Kolleru lake water, which is also demonstrated in this study through estimation of carcinogenic health risk assessment due to $\mathrm{Cr}$ ingestion. Two other metals, $\mathrm{Zn}$ and Fe, represent average $H Q$ ratios that are either close to $1(\mathrm{Zn}=0.99)$ or very less $(\mathrm{Fe}=0.09)$.

The comparison study made here on the calculated $H I$ is extremely significant. An overall insight as to how the Kolleru lake water must have been affected due to presence of dissolved heavy metals as a consequence of anthropogenic activities was plotted in Figure 5d. In this diagram the estimated HIaverage values for adults and children via ingestion and dermal pathways are displayed (Figure $5 \mathrm{~d}$ ). The $H I$ values are also estimated based on median values of concentration of the same toxic elements [38] reported for global clean and uncontaminated surface waters (Figure 5d). These latter values are also displayed against HIaverage of Kolleru lake water for comparison. Marked differences can be noticed between the two sets of $H I$ values (Figure $5 \mathrm{~d}$ ), indicating the degradation of water quality of the lake.

It is significant to mention that presence of various types of macrophytes such as Eichhornia crassipes, Pennisetum purpureum, Salvania sp., Ipomea aquatica and many others have been noticed within the Kolleru lake during the field survey. The toxic metal removal potential of water hyacinth was evaluated by Stephenson et al. [47] It was found by these researchers that E. crassipes can be used as remediator plants for several toxic metals like $\mathrm{Cd}, \mathrm{Co}, \mathrm{Cr}, \mathrm{Cu}, \mathrm{Fe}, \mathrm{Pb}$ etc. Likewise, to improve 
the water quality, the role of macrophytes by preferentially scavenging different heavy metals was also reviewed [48]. In view of the above two studies, it is inferred that the estimated $H Q$ values pertaining to various heavy metals in water of the Kolleru lake may be considered as the minimum limit. The heterogeneous distribution of $H Q$ values displayed in Figure 3 and 4 explains the metal scavenging role of macrophytes. Although with the available data it is difficult to point out the exact source/sources and assess the relative contribution of each source for the observed heterogeneous distribution of $H Q$ values in the lake water, it is certain that unchecked anthropogenic activities in and around the Kolleru lake area are responsible for the degradation of its water quality. In this context it is pertinent to mention that the Andhra Pradesh Government initiated a task called "Operation Kolleru" during 2005-2006. The main aim of this task was to ensure traditional activities only and to do away with all encroachments within the designated site of the lake so that free flow of water is restored. After the operation was over, migratory birds started returning to the lake, which caught attention of many. Subsequent publications also reported retrieval of the lake ecosystem [49,50]. However, recent studies reveal that several anthropogenic activities have once again picked up momentum within the lake and its surroundings [23,24,51]. Despite negligible potential non-carcinogenic health risk of either direct intake or other uses of lake water as indicated by $<1 H Q$ and $H I$ values (Figure 3, 4, and 5), this study demonstrates that the ratios between estimated average $H Q$ values associated with various heavy metals like $\mathrm{Cr}, \mathrm{Cu}$ and $\mathrm{Mn}$ dissolved in Kolleru lake water and global surface water is high (Table 1 and Figure $5 c$ and $5 d$ ). Therefore, there is an urgent need to stop further degradation of the lake and its surroundings. In order to ensure sustenance of the lake's health, concerted efforts are needed on local and regional scales.

\section{Conclusion and recommendation}

(i) The individual $H Q_{\text {ingestion }} H Q_{\text {dermal }}$ values are estimated to be less than 1 for the heavy metals dissolved in Kolleru lake water. Such low values are indicative of an acceptable level of non-carcinogenic health risk for the heavy metals dissolved in water.

(ii) The average HIingestion and HIdermal, for both adults and children are also less than 1 , suggesting negligible amount of overall adverse health risk.

(iii) Water intake represents only a proportion of fluid consumed. However, taking other food items such as fish of the lake and rice grown in the lake surroundings when consumed, can have adverse health effect. Because in such case, cumulative ingestion candidates may contribute to intake of increased amounts of heavy metals.

(iv) As far as average $C$ Ringestion levels of the adults and children due to $\mathrm{Cr}$ are concerned, high $C R_{\text {ingestion values of }}$ 0.00154 and 0.0022 , respectively are estimated for adults and children. Both these values are higher than the permissible levels [46].

(v) It is therefore recommended that monitoring the levels of heavy metal in water and other items like fish of the lake, rice and vegetables grown in the area need to be carried out at regular intervals.

(vi) In view of the phytoremediation potential of various species discussed in the literature [47,48], one of the most pertinent questions that may arise is whether to eliminate or maintain the macrophytes in the lake ecosystem. This is particularly important in view of sampling site \#7, where anomalously high concentration of $\mathrm{Cr}$ is registered. As a mitigation measure, it is therefore suggested that the phytoextraction process may be continued for some more time, even if it is at the expense of restriction of free flow of water in the lake. However, once the phytoextraction processes are over, the macrophyte species need to be disposed safely during the initial stages of restoration phase of the lake. Subsequently, if the domestic and industrial effluents are allowed to discharge into the lake, proper treatment becomes mandatory to ensure no toxicity.

(vii) The natural macrophytes that preferentially scavenge heavy metals and present in the lake need to be disposed periodically after the phytoextraction processes. In this context, strategies may be made about their safe disposal. For example, Sas-Nowosielska et al. [52] examined a large number of strategies that include composting, compaction, incineration, ashing, pyrolysis, direct disposal, liquid extraction, etc. They suggested that incineration (smelting) is the most feasible, economically viable and environmentally friendly method. However, there are other researchers who proposed that pyrolysis of hyperaccumulator biomass is the most suitable method [53,54]. According to them, the char can be considered a rich "ore" or metal concentrate, which can be processed for possible separation of the metal in an ore-processing unit. Such mitigation measures could prove to be extremely beneficial for long-term sustenance of the lake ecosystem.

(viii) The results presented in this study and recommendation made thereof is expected to provide adequate insight to the local government and health professionals to evolve strategies to effectively manage and mitigate the water quality of the Kolleru lake.

\section{Acknowledgement}

I am grateful to Jung-Hwan Kwon, Editor-in-Chief for efficient handling and useful suggestions. Two anonymous reviewers are acknowledged for critical evaluation of the manuscript. Suggestions made by them have helped in improving the manuscript. 


\section{Conflict of interest}

The author declares no conflict of interest associated with the material presented in this paper.

\section{ORCID}

Subrata Das Sharma: 0000-0001-7053-2115

\section{References}

[1] Gržetić I, Ghariani ARH. Potential health risk assessment for soil heavy metal contamination in the central zone of Belgrade (Serbia). J Serbian Chem Soc 2008;73(8-9):923-934.

[2] Rizwan SA, Nongkynrih B, Gupta SK. Air pollution in Delhi: Its magnitude and effects on health. Indian J Community Med 2013;38(1):4-8.

[3] Saha N, Rahman MS, Ahmed MB, Zhou JL, Ngo HH, Guo, W. Industrial metal pollution in water and probabilistic assessment of human health risk. J Environ Manag 2017;185:70-78.

[4] Vetrimurugan E, Brindha K, Elango L, Ndwandwe OM. Human exposure risk to heavy metals through groundwater used for drinking in an intensively irrigated river delta. Appl Water Sci 2017;7(6):3267-3280.

[5] Qu CS, Ma ZW, Yang J, Liu Y, Bi J, Huang L. Human exposure pathways of heavy metals in a lead-zinc mining area, Jiangsu Province, China. PloS One 2012;7(11):e46793.

[6] Shah MT, Ara J, Muhammad S, Khan S Tariq S. Health risk assessment via surface water and sub-surface water consumption in the mafic and ultramafic terrain, Mohmand agency, northern Pakistan. J Geochem Explor 2012;118, 60-67.

[7] Osseiran N, Lufadeju Y. 1 in 3 people globally do not have access to safe drinking water - UNICEF, WHO. 2019, [cited 2020 July 20] Available from: https://www.who.int/news-room/detail/18-06-2019-1-in-3-people-globally-do-nothave-access-to-safe-drinking-water-unicef-who

[8] National Research Council (NRC). Drinking water and health. national academy of sciences. National Academy Press: Washington DC. 1977, 1-939.

[9] National Research Council (NRC). Risk assessment in the federal government: managing the process. National Academy Press: Washington DC. 1983, 1-191.

[10] National Research Council (NRC). Drinking water and health. Vol. 6. National Academy Press: Washington DC. 1986, $1-457$.

[11] El Attar L, Gawad AA, Khairy AEM, El Sebaie O. The sanitary condition of rural drinking water in a Nile delta village: II. Bacterial contamination of drinking water in a Nile Delta village. J Hydrogeol 1982;88(1):63-68.

[12] Kim YS, Park HS, Kim JY, Park SK, Cho BW, Sung IH et al. Health risk assessment for uranium in Korean groundwater. J Environ Radioactivity 2004;77(1):77-85.

[13] Kamunda C, Mathuthu M, Madhuku M. Health risk assessment of heavy metals in soils from Witwatersrand gold mining basin, South Africa. Intl J Environ Res Public Health 2016;13(7):663.

[14] Food and Agriculture Organization of the United Nations (FAO). Lakes and rivers key to livelihoods of millions. 2015, [cited 2020 July 16] Available from: http://www.fao.org/news/story/en/item/276122/icode/

[15] Olayinka OO, Adedeji HO, Akinyemi AA, Oresanya OJ. Assessment of the pollution status of Eleyele Lake, Ibadan, Oyo State, Nigeria. J Health Pollution 2017;7(15):51-62.

[16] Zhang J, Li Y, Liu C, Li F, Zhu L, Qiu Z, et al. Concentration levels, biological enrichment capacities and potential health risk assessment of trace elements in Eichhornia crassipes from Honghu lake, China. Sci Rep 2019;9(1):1-12.

[17] Gupta SC, Rathore GS, Mathura GC. Hydro-chemistry of Udaipur lakes. Indian J Environ Health 2001;43(1):38-44.

[18] Iwasaki S, Shaw R. Linking human security to natural resources: perspective from a fishery resource allocation system in Chilika lagoon, India. Sustain Sci 2009;4(2):281-292. 
[19] Zutshi DP, Khan AU. Eutrophication gradient in Dal lake, Kashmir. Indian J Environ Health 1988;30(4):348-354.

[20] Environmental Information System (ENVIS). Centre on wildlife \& protected areas. RAMSAR Wetland Sites. 2011, [cited 2020 September 08] Available from: http://wiienvis.nic.in/Database/ramsar_wetland_sites_8224.aspx

[21] Amaraneni SR, Pillala RR. Concentration of pesticide residue in tissues of fish from Kolleru lake, India. Environ Toxicol 2001;16(6):550-556.

[22] Sekhar KC, Chary NS, Kamala CT, Raj DS, Rao AS. Fractionation studies and bioaccumulation of sediment-bound heavy metals in Kolleru lake by edible fish. Environ Intl 2004;29(7):1001-1008.

[23] Sharma SD. Risk assessment and mitigation measures on the heavy metal polluted water and sediment of the Kolleru lake in Andhra Pradesh, India. Pollution 2019;5(1):161-178.

[24] Sharma SD, Sujatha D. Characterization of the water chemistry, sediment $13 \mathrm{C}$ and $18 \mathrm{O}$ compositions of Kolleru lakea Ramsar wetland in Andhra Pradesh, India. Environ Monit Assess 2016;188(7):409.

[25]Rao KN, Krishna GM, Malini BH. Kolleru lake is vanishing - a revelation through digital processing of IRS-1D LISS-III sensor data. Curr Sci 2004;86(9):1312-1316.

[26] The Hans India. Not a drop to drink in Kolleru region. 2016, [cited 2020 July 26] Available from: https:/www.thehansindia.com/posts/index/Andhra-Pradesh/2016-02-26/Not-a-drop-to-drink-in-Kolleruregion/209847

[27] Azeez PA, Kumar SA, Choudhury BC, Sastry VNVK, Upadhyay S, Reddy KM, et al. Report on the proposal for downsizing the Kolleru wildlife sanctuary ( +5 to +3 feet contour). Submitted to the Ministry of Environment and Forests, Government of India. 2011, [cited 2020 July 22] Available from: www.thehindu.com/multimedia/.../Kolleru Report9 pri 549380a.pdf .

[28] Amaraneni SR. Studies on pollution problems of Kolleru Lake with special reference to pesticides, polycyclic aromatic hydrocarbons and heavy metals. [dissertation] Vishakapatnam, India: Andhra University; 1997.

[29] United State Environmental Protection Agency (USEPA). Methods for chemical analysis of water and wastes. Cincinnati, Ohio, USA. EPA-600/4-79-020;1983.

[30] American Public Health Association (APHA). Standard methods for the examination of water and wastewater. 19th ed. American Public Health Association: Washington DC, USA. 1995.

[31] United State Environmental Protection Agency (USEPA). Human health risk assessment. 2016, [cited 2020 September 08] Available from: https://www.epa.gov/risk/human-health-risk-assessment

[32] United State Environmental Protection Agency (USEPA). Risk assessment guidance for superfund Volume I: human health evaluation manual (Part A). Washington DC, USA. EPA/540/1-89/002; 1989.

[33United State Environmental Protection Agency (USEPA). Risk assessment guidance for superfund Volume I: human health evaluation manual (Part E, Supplemental Guidance for Dermal Risk Assessment). Washington DC, USA. EPA/540/R/99/005, OSWER 9285.7-02EP, PB99-963312; 2004.

[34] Milton AH, Rahman H, Smith W, Shrestha R, Dear K. Water consumption patterns in rural Bangladesh: are we underestimating total arsenic load? J Water Health 2006;4(4):431-436.

[35] Iglesia I, Guelinckx I, De Miguel-Etayo PM, González-Gil EM, Salas-Salvadó J, Kavouras SA et al. Total fluid intake of children and adolescents: cross-sectional surveys in 13 countries worldwide. Eur J Nutr 2015;54:57-67.

[36] Swaminathan S, Sinha S, Minocha S, Makkar S, Kurpad AV. Are we eating too much? A critical reappraisal of the energy requirement in Indians. Proc Indian Natl Sci Acad 2018;84(4):809-819.

[37] Freeze RA, Cherry JA. Groundwater. Prentice Hall Inc; 1979.

[38] Langmuir D. Aqueous environmental geochemistry. Prentice Hall; 1997. 
[39] Integrated Risk Information System (IRIS). Chemical assessment summary chromium (VI) (CASRN 18540-29-9). [cited 2020 August 08] Available from: https://cfpub.epa.gov/ncea/iris/iris_documents/documents/subst/0144_summary.pdf\#nameddest=canceroral

[40] Mahmoud MT, Hamouda MA, Al Kendi RR, Mohamed MM. Health risk assessment of household drinking water in a district in the UAE. Water 2018;10(12):1726.

[41] United State Environmental Protection Agency (USEPA). Provisional peer reviewed toxicity values for iron and compounds (CASRN 7439-89-6) Derivation of Subchronic and Chronic Oral RfDs. 2006; EPA/690/R-06/020F Final 911-2006.

[42] Integrated Risk Information System (IRIS). Chemical assessment summary manganese (CASRN 7439-96-5). [cited 2020 August 08] Available from: https://cfpub.epa.gov/ncea/iris/iris_documents/documents/subst/0373_summary.pdf

[43] Integrated Risk Information System (IRIS). Toxicological review of zinc and compounds (CAS No. 7440-66-6). 2005; EPA/635/R-05/002.

[44] Naveedullah MZH, Yu C, Shen H, Duan D, Shen C, Lou L, et al. Concentrations and human health risk assessment of selected heavy metals in surface water of the Siling reservoir watershed in Zhejiang Province, China. Pol J Environ Stud 2014;23(3):801-811.

[45] Office of Environmental Health Hazard Assessment (OEHHA). Chromium-hexavalent (CAS No. 18540-29-9). [cited 2020 September 10] Available from: https://oehha.ca.gov/chemicals/chromium-hexavalent

[46] United State Environmental Protection Agency (USEPA). Guidelines for carcinogen risk assessment. 2005;Federal Register 804,636-640.

[47] Stephenson M, Turner G, Pope P, Knight A, Tchobanoglous G. The use and potential of aquatic species for wastewater treatment. Publ No 65 California State Water Resources Control Board Sacramento, CA; 1980.

[48] Dhote S, Dixit S. Water quality improvement through macrophytes - a review. Environ Monit Assess 2009;152(1-4):149153.

[49] Pattanaik C, Prasad SN, Nagabhatla, N Finlayson CM. Kolleru regains its grandeur. Curr Sci 2008;94(1):9-10.

[50] Nagabhatla N, Sellamuttu SS. Political ecology of wetland management: the post aquaculture demolition case of Lake Kolleru in India. Rev Geogr Acad 2008;2(1):10-19.

[51] Rao KN, Kumar K, Subraelu P, Demudu G, Reddy BV, Malini BH. Kolleru lake revisited: the post "operation Kolleru" scenario. Curr Sci 2010;98:1289-1291.

[52] Sas-Nowosielska A, Kucharski R, Malkowski E, Pogrzeba M, Kuperberg JM, Krynski K. Phytoextraction crop disposalan unsolved problem. Environ Pollut 2004;128(3):373-379.

[53] Koppolu L, Prasad R, Clements LD. Pyrolysis as a technique for separating heavy metals from hyperaccumulators. Part III: pilot-scale pyrolysis of synthetic hyperaccumulator biomass. Biomass Bioenerg 2004;26(5):463-472.

[54] Lehmann J. Bioenergy in the black. Frontiers Ecol Environ 2007;5:381-387. 